\title{
Clinical presentation and prevalence of spontaneous bacterial peritonitis in patients with cryptogenic cirrhosis and features of metabolic syndrome
}

\author{
P Sorrentino $M D^{1}$, G Tarantino $M D^{1}$, $\mathrm{P}$ Conca $M D^{1}, \mathrm{~A}$ Perrella $M D^{2}$, O Perrella $M D^{3}$
}

\begin{abstract}
P Sorrentino, G Tarantino, P Conca, A Perrella, O Perrella. Clinical presentation and prevalence of spontaneous bacterial peritonitis in patients with cryptogenic cirrhosis and features of metabolic syndrome. Can J Gastroenterol 2004;18(6):381-386.
\end{abstract}

BACKGROUND: Nonalcoholic steatohepatitis (NASH) may progress to cirrhosis. The prevalence and clinical relevance that spontaneous bacterial peritonitis may have in complicating ascites due to NASH-related cirrhosis have yet to be defined.

METHODS: Among 611 cases of cirrhosis-associated ascites, 45 patients with cryptogenic cirrhosis were retrospectively identified. Of these, 36 patients and a control group of subjects with viralassociated ascites were followed up and compared in a case control study. Information on the onset of ascites, with or without spontaneous bacterial peritonitis, history of risk factors for multimetabolic syndrome, and serological and ascitic laboratory data were compared between groups.

RESULTS: Spontaneous bacterial peritonitis occurred significantly more often in patients with cryptogenic cirrhosis than in equally symptomatic viral controls. The prevalence of obesity, diabetes and spontaneous bacterial peritonitis was significantly higher in patients with cryptogenic cirrhosis. Although liver function was similar in both groups, cryptogenic cirrhosis patients had lower aminotransferase levels. Multivariate analysis identified diabetes, juvenile obesity and spontaneous bacterial peritonitis as independent factors associated with ascites due to cryptogenic cirrhosis.

CONCLUSIONS: Features suggestive of NASH are more frequently observed in patients with ascites and cryptogenic cirrhosis than in age- and sex-matched ascitic patients with well-defined viral etiology. Ascites may be a presenting symptom of NASH-related cirrhosis, and affected patients have a twofold greater risk of spontaneous bacterial peritonitis.

Key Words: Ascites; Metabolic syndrome; Nonalcoholic fatty liver disease; Nonalcoholic steatohepatitis; Spontaneous bacterial peritonitis
La présentation clinique et la prévalence de la péritonite bactérienne spontanée chez les patients atteints de cirrhose cryptogénique et les caractéristiques du syndrome métabolique

HISTORIQUE : La stéatohépatite non alcoolique (SHNA) peut se détériorer en cirrhose. La prévalence et la pertinence clinique potentielles d'une péritonite bactérienne spontanée à compliquer les ascites en raison d'une cirrhose reliée à une SHNA n'ont pas encore été définies. MÉTHODOLOGIE : Sur les 611 cas d'ascites associées à une cirrhose, 45 patients atteints de cirrhose cryptogénique ont fait l'objet d'un dépistage rétrospectif. De ce nombre, 36 patients et un groupe témoin atteints d'ascites d'origine virale ont été suivis et comparés dans le cadre d'une étude cas-témoin. L'information sur l'apparition des ascites, avec ou sans péritonite bactérienne spontanée, les antécédents de facteurs de risque de syndrome multimétabolique et les données de laboratoire sérologiques et ascitiques ont été comparés entre les groupes.

RÉSULTATS : La péritonite bactérienne spontanée se manifestait beaucoup plus chez les patients atteints de cirrhose cryptogénique que chez des témoins viraux tout aussi symptomatiques. La prévalence d'obésité, de diabète et de péritonite bactérienne spontanée était beaucoup plus élevée chez les patients atteints de cirrhose cryptogénique. Bien que la fonction hépatique soit similaire dans les deux groupes, les patients atteints de cirrhose cryptogénique présentaient des taux d'aminotransférases plus faibles. L'analyse multivariée a permis d'établir que le diabète, l'obésité juvénile et la péritonite bactérienne spontanée étaient des facteurs indépendants associés à des ascites causées par une cirrhose cryptogénique.

CONCLUSIONS : Les caractéristiques suggérant une SHNA sont plus observées chez les patients ascitiques et atteints de cirrhose cryptogénique que chez des patients ascitiques à l'étiologie virale bien définie et appariés selon l'âge et le sexe. Les ascites sont peut-être un facteur de présentation de cirrhose secondaire à une SHNA, et les patients atteints courent un risque deux fois plus élevé de péritonite bactérienne spontanée.

diabetes (8-10), hyperlipidemia (8,11-13) and insulin resistance $(13-16)$, which are the main features of this recently characterized metabolic syndrome (17). In most cases, fatty liver does not progress to more severe liver disease, but in nearly $20 \%$ to $30 \%$ of patients, there are histological signs of fibrosis and necroinflammation, thus implying the presence of

$\mathrm{N}$ onalcoholic fatty liver disease (NAFLD) accounts for approximately $80 \%$ of cases of elevated liver enzyme levels in the American population; one individual in every four or five American adults actually has NAFLD $(1,2)$. Similar data have been also reported for the Japanese (3) and Italian $(4,5)$ populations. NAFLD is mainly associated with obesity $(6,7)$,

${ }^{1}$ Hepatology Unit in Internal Medicine, Department of Clinical and Experimental Medicine, and ${ }^{2}$ Department of Infectious Disease of Federico II

University Medical School; ${ }^{3}$ VIIth Department of Infectious Disease and Immunology, Naples, Italy

Correspondence: Dr G Tarantino, Department of Clinical and Experimental Medicine, Federico II University Medical School,

Via S Pansini 5, 80131 Naples, Italy. Telephone/fax 3-98-1-746-2024, e-mail tarantin@unina.it

Received for publication September 9, 2003. Accepted April 5, 2004 
nonalcoholic steatohepatitis (NASH) $(8,18)$. In the past, patients with clinical aspects of metabolic syndrome and cirrhosis without a well-defined etiology were considered as having cryptogenic cirrhosis (CC) (19); these patients are at risk of developing terminal liver failure (19) and hepatocellular carcinoma (20). Ascites and spontaneous bacterial peritonitis (SBP) are potentially life-threatening complications in patients with cirrhosis of known etiology. In postviral cirrhosis, SBP may be complicated by renal failure, systemic sepsis and recurrence, leading to poor survival $(21-23)$. The prevalence of SBP in hospitalized patients with cirrhosis of known origin is between $10 \%$ and $30 \%(24,25)$. Ascites are also part of the natural history of NASH-related CC (26), but no data are available on the prevalence and clinical presentation of SBP in hospitalized patients with CC-related ascites. Against this background, our study aimed to verify the following: the prevalence of metabolic syndrome (ie, risk factors associated with NASH) in patients with CC related ascites; the prevalence of SBP in CC patients hospitalized for a first evaluation of ascites; and clinical presentation of ascites with or without SBP in patients with CC. We used an age- and sexmatched group of patients with ascitic cirrhosis of well recognized viral cause as controls.

\section{Patients}

\section{PATIENTS AND METHODS}

Using the medical records of the Hepatology Unit of the Department of Clinical and Experimental Medicine of the Federico II University Medical School and of the VIIth Division of Infectious Disease at D Cotugno Hospital in Naples, Italy, 819 white patients hospitalized from 1992 to 2002 with a diagnosis of newly discovered ascites were identified. These patients were included in an extensive study as part of a diagnostic work up for the first evaluation of ascites. Of these, 611 patients had ascites superimposed on liver cirrhosis. The diagnosis of cirrhosis was made by either histological criteria or clinical, analytical and ultrasonographic findings; the authors had sufficient data to establish the etiology of liver disease for most of the patients. The clinical history and laboratory data failed to identify any recognizable cause in 45 ( 34 females) patients, who were therefore classified as having CC. Of these patients, 36 (24 females) were still being actively followed and represent the population in the present report. For each index case, the authors identified in their files the two closest hepatitis C virus (HCV)- and one closest hepatitis B virus (HBV)-related ascitic cirrhotic patients, who were consecutively selected and matched for age ( \pm 6 years) and sex. Patients with hemochromatosis, primary biliary cirrhosis or autoimmune liver disease were not considered because of difficulties in matching with the cryptogenic group; some sporadic cases of chylous ascites were also excluded. Patients with mixed etiology (simultaneous presence of at least two of the following conditions: HBV, $\mathrm{HCV}$, excessive alcohol intake, hemochromatosis and coinfection of HBV with Delta virus) were also excluded. Thus, 108 patients acted as control subjects for the present study. The study protocol was approved by the senior staff committee of the Department of Clinical and Experimental Medicine of the Federico II University Medical School.

\section{Data collection}

All patients were re-evaluated and the following data were recorded: history of liver disease among first degree relatives, recent onset of symptoms leading to the diagnosis of ascites or
SBP, history of diabetes and dyslipidemia (hypercholesterolemia and hypertriglyceridemia), presence of coronary artery disease and hypertension, personal history of alcohol intake, intravenous drug use and blood transfusion. Information on alcohol consumption was self-reported and confirmed by interviewing a family member. Patients with alcohol consumption greater than $140 \mathrm{~g} /$ week were excluded from the CC group.

The diagnosis of diabetes mellitus was based on the American Diabetes Association criteria (17). Type, age at onset, duration of diabetes and current therapy were recorded. Coronary artery disease was assessed during the interview and confirmed by the medical files of the patients' primary care physicians. Height and weight were measured. Hypertension was diagnosed if the patient had a past history of hypertension, was taking antihypertensive medication, or had a resting recumbent blood pressure of $140 / 90 \mathrm{mmHg}$ or higher on at least two occasions. Hypercholesterolemia was defined as a serum cholesterol level greater than $5.18 \mathrm{mmol} / \mathrm{L}$; hypertriglyceridemia, if serum triglyceride levels were greater than $2.26 \mathrm{mmol} / \mathrm{L}$. Body mass index (BMI) was calculated as weight $(\mathrm{kg})$ divided by squared height $\left(\mathrm{m}^{2}\right)$. This index was measured after the partial or total resolution of ascites. Obesity was defined as BMI greater than $30 \mathrm{~kg} / \mathrm{m}^{2}$; overweight as BMI between $25 \mathrm{~kg} / \mathrm{m}^{2}$ and $29.9 \mathrm{~kg} / \mathrm{m}^{2}$. Because cirrhosis may be related to changes in body mass, with or without clinical ascites, each patient's history of obesity was investigated by collecting information on average weight 2.0 to 2.5 years before the diagnosis of cirrhosis.

Serological testing included anti-HCV antibody and HBV markers. The following laboratory tests were also performed in all cases: antinuclear, antimitochondrial and antiliver kidney

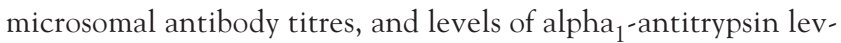
els, total bilirubin, alanine transaminase (ALT), aspartate transaminase, alkaline phosphatase, albumin, gamma-glutamin transferase, prothrombin activity, quantitative immunoglobulin, iron storage parameters (ferritin, iron, transferring saturation), copper, ceruloplasmin, serum cholesterol and triglyceride. Fasting glucose and insulin levels were determined and used to calculate the homeostasis model assessment parameters of insulin resistance (HOMA-R) (27). This test shows a good correlation with the hyperinsulinemic euglycemic clamp technique, the gold standard for quantitative assessment of insulin sensitivity $(28,29)$. The occurrence of H63D and C282Y mutations in the HFE gene of familial hemochromatosis was also determined.

During hospitalization, patients underwent diagnostic paracentesis, and the ascitic fluid was classically processed for cytology, polymorphonuclear (PMN) leukocyte and lymphocyte count, and appropriate biochemical tests (glucose, total protein, albumin, amylases, lactate dehydrogenase). The ascitic sample for PMN leukocyte and total leukocyte count was collected into a heparin anticoagulant tube and analyzed within $3 \mathrm{~h}$ of extraction. Cell count was performed on a hematological instrument (Pentra 120; ABX Diagnostics, France). The ascitic fluid sample was centrifuged at $2500 \mathrm{~g}$ for $10 \mathrm{mins}$. A smear was performed with the cellular bottom and stained with May-Grumwald-Giemsa. Cytological examination and differential cell count were made using a conventional optical microscope. Ascitic cultures were made by inoculating $10 \mathrm{~mL}$ of ascitic fluid into a bottle containing $25 \mathrm{~mL}$ of liquid culture (BD BACTEC; Becton, Dickinson and Company, Ireland). The bottle was placed in the Bactec instrument and processed according to the manufacturer's instructions. SBP was defined as a PMN leukocyte count in ascitic fluid greater than $250 \mathrm{~mm}^{3}$, in the absence of any intra-abdominal source of infection and after 
excluding other causes of elevated PMN leukocytes in ascitic fluid such as tuberculosis, peritoneal carcinomatosis or pancreatitis.

\section{Statistical analysis}

All analyses were carried out with a personal computer using MedCalc software (Belgium). Results were specifically expressed as median with $95 \% \mathrm{CI}$ for each discrete variable. The paired Wilcoxon test was used to calculate the significance of betweengroup differences, while the McNemar test was used to compare proportions. This case control study (ratio 1:3) was managed with nonparametric statistics. Logistic regression analysis was used to identify the factors significantly associated with $\mathrm{CC}$ in patients with ascites (univariate analysis). Only the factors carrying significant risk were included in a stepwise multivariate analysis. Significance limit was set to $\mathrm{P}<0.05$.

\section{RESULTS}

The prevalence of $\mathrm{CC}$ in the 611 patients with cirrhotic ascites was $7.36 \%$, compared to $59 \%$ in patients with HCVrelated cirrhosis, $12.9 \%$ in patients with HBV-related cirrhosis, $9.1 \%$ in patients with alcohol-related cirrhosis, $9.5 \%$ in patients with mixed etiology and $2.14 \%$ in patients with hemochromatosis and primary biliary cirrhosis/autoimmune cholangitis. Patients with CC and ascites were older compared with the entire unmatched group of ascitic patients (67 years [64 to 69] versus 59 years [53 to 63], respectively, $\mathrm{P}<0.05)$. The proportion of females was higher in the case group of CC patients with ascites than in the entire unmatched group of patients with ascites of well-defined etiology (67\% [24 of 36] versus 46\% [281 of 611], respectively, $\mathrm{P}<0.01)$.

Because none of the variables examined showed any significant difference between the viral subsets (HBV and HCV etiology) in the control group (data not shown), these patients were considered as a single control group for the purpose of the statistical analysis. The mean duration of cirrhosis history before the diagnosis of ascites was $1.3 \pm 2.64$ years in the CC group and $10.8 \pm 5.8$ years in the control group $(\mathrm{P}<0.001)$.

The main clinical and laboratory data of patients included in the case control study are reported in Table 1. Most of the cases and controls were classified as Child-Pugh's Class B. although the authors were unable to exactly determine the score due to difficulties in assessing the severity of ascites and encephalopathy from medical records. Given the inclusion criteria, there was no age difference between the CC group and the control group. BMI was higher in the CC group than in the control group, both at the time of the evaluation and when considering the reported weight 2.0 to 2.5 years before the diagnosis of cirrhosis. Type II diabetes and hypertension were more common in patients with CC than in the viral etiology control group. The median age at diagnosis of diabetes was 51 years (95\% CI 39 to 59 ) in the CC group and 60 years (51 to 68$)$ in the control group $(\mathrm{P}<0.01)$. Previous dyslipidemia, including hypercholesterolemia and hypertriglyceridemia, was observed more frequently in patients with CC than in the control group. Coronary artery disease was not associated with CC. CC patients had lower aminotransferase levels, with ALT being in the normal range in $80 \%$ of cases, compared within $15 \%$ of controls $(\mathrm{P}<0.01)$. Blood glucose, insulin and the indexes of insulin resistance (HOMA-R) were significantly higher in the CC group than in the control group. Cholesterol and triglycerides were also higher in the CC group, but there were no differences in routine liver function tests and
TABLE 1

Clinical and laboratory data of patients with ascites and
cirrhosis

\begin{tabular}{|c|c|c|}
\hline & $\begin{array}{l}(n=36) \\
\text { rryptogenic cirrhosis }\end{array}$ & $\begin{array}{l}\text { Controls: All cases } \\
(n=108)\end{array}$ \\
\hline Age (years) & $65(63-67)$ & $64(61-66)$ \\
\hline BMI $\left(\mathrm{kg} / \mathrm{m}^{2}\right)$ & $28(27.8-30)$ & $24.4(23-27)^{*}$ \\
\hline $\begin{array}{l}\text { Juvenile precirrhosis } \\
\text { BMI }\left(\mathrm{kg} / \mathrm{m}^{2}\right)\end{array}$ & $30.5(28-35)$ & $22(20-23)^{*}$ \\
\hline \multicolumn{3}{|l|}{ Laboratory data on ascites (\%) } \\
\hline $\begin{array}{l}\text { Absolute neutrophil count } \\
>250 / \mathrm{mm}^{3} \text { (neutrocytic ascites) }\end{array}$ & $58 \%(21 / 36)$ & $23 \%(25 / 108)^{*}$ \\
\hline $\begin{array}{l}\text { Culture positive neutrocytic } \\
\text { ascites }\end{array}$ & $42 \%(15 / 36)$ & $40 \%(43 / 108)$ \\
\hline Ascitic fluid total proteins $<10 \mathrm{~g} / \mathrm{L}$ & /L $53 \%(19 / 36)$ & $23 \%(25 / 108)^{*}$ \\
\hline \multicolumn{3}{|c|}{ Clinical data $(\%)^{\dagger}$} \\
\hline Hypertension & $42 \%(15 / 36)$ & $24 \%(26 / 108)^{*}$ \\
\hline Coronary artery disease & $8.3 \%(3 / 36)$ & $5.5 \%(6 / 108)$ \\
\hline $\begin{array}{l}\text { Hypertriglyceridemia } \\
(>2.26 \mathrm{mmol} / \mathrm{L})\end{array}$ & $28 \%(10 / 36)$ & $1.85 \%(2 / 108)^{*}$ \\
\hline $\begin{array}{l}\text { Hypercholesterolemia } \\
(>5.18 \mathrm{mmol} / \mathrm{L})\end{array}$ & $47.2 \%(17 / 36)$ & $8.3 \%(9 / 108)^{*}$ \\
\hline Type 2 diabetes mellitus & $50 \%(18 / 36)$ & $9.2 \%(10 / 108)^{*}$ \\
\hline \multicolumn{3}{|l|}{ Laboratory data } \\
\hline INR & $1(0.9-1.2)$ & $1.3(0.9-1.4)$ \\
\hline Serum bilirubin $(\mu \mathrm{mol} / \mathrm{L})$ & $20.52(15.4-22.2)$ & $22.2(20.5-22.2)$ \\
\hline Serum albumin $(\mathrm{g} / \mathrm{L})$ & $30.5(28-32)$ & $32(30-34)$ \\
\hline Transferrin saturation (\%) & $28(26-29)$ & $27(25-28)$ \\
\hline Serum ferritin $(\mu \mathrm{g} / \mathrm{L}, \times$ uln $)$ & $0.9(0.8-1.3)$ & $1.15(0.9-1.3)$ \\
\hline C282Ymutation (\%) & 0 & 0 \\
\hline H63D mutation (\%) & $11(4 / 36)$ & $14(15 / 108)$ \\
\hline $\begin{array}{l}\text { Fasting serum blood glucose } \\
(\mathrm{mmol} / \mathrm{L})\end{array}$ & $7.48(6.18-8.45)$ & $5.4(4.95-5.8)^{\star}$ \\
\hline HOMA-R (\%) & $8.7(6.3-9.4)$ & $2.65(2.3-3.2)^{\star}$ \\
\hline Serum cholesterol (mmol/L) & $4.20(4.06-4.43)$ & $3.56(3.31-3.65)^{\star}$ \\
\hline Serum triglycerides (mmol/L) & $1.83(1.68-2.01)$ & $1.24(1.12-1.57)^{*}$ \\
\hline Alanine transaminase $(\mathrm{U} / \mathrm{L})^{\ddagger}$ & $38(29-44)$ & $69.5(58-88)^{\star}$ \\
\hline Aspartate transaminase $(\mathrm{U} / \mathrm{L})^{\ddagger}$ & $37(27-46)$ & $77(55-96)^{*}$ \\
\hline
\end{tabular}

Data are expressed as median with $95 \% \mathrm{Cl}$ or percentage and number of patients with respect to total patients of the specific group. *Significance of difference versus cryptogenic cirrhosis, $P<0.05$; ${ }^{\dagger}$ Clinical data refer to past or present evidence of disease; $¥$ Normal value $<40$ U/L. BMI Body mass index; HOMA-R Homeostasis model assessment parameters of insulin resistance; INR International normalized ratio; uln Upper limit of normal

Child-Pugh scores compared with controls. Iron status was similar between groups; there were no cases of familial hemochromatosis in either the $\mathrm{CC}$ or the control group. The characteristics of ascites differed for the significantly higher number of cases of SBP among CC patients.

The univariate analysis (Table 2) confirmed that clinical history of obesity (recent and juvenile precirrhosis obesity), hypertension, diabetes, dyslipidemia, elevated fasting glucose, insulin resistance and normal values of ALT and SBP were associated with CC. Multivariate analysis identified type II diabetes, juvenile precirrhosis obesity and SBP as independent predictors of ascites superimposed on CC. The onset of symptoms that led to the diagnosis of ascites are shown in Table 3. 
TABLE 2

Risk factors associated with cryptogenic cirrhosis among subjects with ascites

\begin{tabular}{|c|c|c|c|}
\hline & Odds ratio & $95 \% \mathrm{Cl}$ & $\mathbf{P}$ \\
\hline \multicolumn{4}{|l|}{ Univariate analysis } \\
\hline Age (years)/10 & 1.52 & $0.8-2.4$ & 0.196 \\
\hline \multicolumn{4}{|l|}{ Laboratory data on ascites (\%) } \\
\hline $\begin{array}{l}\text { Absolute neutrophil count }>250 / \mathrm{mm}^{3} \\
\text { (neutrocytic ascites) }\end{array}$ & 5.3 & $3.2-6.5$ & 0.003 \\
\hline \multicolumn{4}{|l|}{ Clinical data* } \\
\hline Hypertension & 3.7 & $2.3-6.5$ & 0.002 \\
\hline Coronary artery disease & 1.2 & $0.8-1.4$ & 0.631 \\
\hline Hypertriglyceridemia (>2.26 mmol/L) & 4.5 & $2.2-6.7$ & 0.003 \\
\hline Hypercholesterolemia $(>5.18 \mathrm{mmol} / \mathrm{L})$ & 2.3 & $1.9-4.8$ & 0.089 \\
\hline Type II diabetes mellitus & 6.5 & $3.7-8.7$ & 0.0004 \\
\hline Obesity & 2.4 & $1.2-4.6$ & 0.005 \\
\hline Overweight & 0.9 & $0.2-2.1$ & 0.891 \\
\hline Juvenile precirrhosis obesity & 6.9 & $4.2-7.8$ & 0.0008 \\
\hline \multicolumn{4}{|l|}{ Laboratory data } \\
\hline Fasting serum blood glucose $(\mathrm{mmol} / \mathrm{L}) / 10$ & $0 \quad 1.6$ & $1.1-2.9$ & 0.003 \\
\hline HOMA-R (\%) & 1.9 & $1.3-3.3$ & 0.007 \\
\hline Serum cholesterol $(\mathrm{mmol} / \mathrm{L}) / 20$ & 1.7 & $1.4-3.5$ & 0.008 \\
\hline Serum triglycerides $(\mathrm{mmol} / \mathrm{L}) / 20$ & 3.2 & $2.4-4.7$ & 0.0001 \\
\hline Alanine transaminase $(\mathrm{U} / \mathrm{L}) / 10$ & 0.6 & $0.4-0.8$ & 0.098 \\
\hline \multicolumn{4}{|l|}{ Multivariate analysis } \\
\hline Type II diabetes mellitus & 4.5 & $3.1-6.3$ & 0.017 \\
\hline Juvenile precirrhosis obesity & 7.8 & $5.2-9.9$ & 0.023 \\
\hline \multicolumn{4}{|l|}{ Absolute neutrophil count $>250 / \mathrm{mm}^{3}$} \\
\hline (neutrocytic ascites) & 5.2 & $4.4-8.9$ & 0.047 \\
\hline
\end{tabular}

${ }^{*}$ Clinical data refer to past or present evidence of disease. HOMA-R Homeostasis model assessment parameters of insulin resistance

\section{DISCUSSION}

We selected a control population with ascites of identifiable etiology for this study; CC-associated ascites were identified after careful exclusion of any potential bias. In particular, the amount of alcohol consumption necessary to meet the criteria for the diagnosis of NASH is an important issue. Because the hepatotoxic dose of alcohol in the general population may be as low as 20 to $30 \mathrm{~g} /$ day in females and $40 \mathrm{~g} /$ day in males (30), we chose to set a daily alcohol consumption below these amounts. Our control group was well-balanced with the CC group for age and sex, but when all of the 611 patients with ascites were considered, those with CC were older. This may reflect a longer survival or a later onset of ascites in the CC group, suggesting a slower progression of NASH to cirrhosis and its complications. The time from cirrhosis to ascite development seems shorter in the CC group, perhaps due to a later diagnosis in these patients; this is most likely attributable to a low index of suspicion of liver disease in patients with negative viral markers and, in many cases, normotransaminasemia (Table 1). Indeed, 26 of 36 patients (72\%) in the CC-related ascite group versus 18 of 108 patients $(16 \%)(\mathrm{P}<0.001$; Table 3$)$ in the control group were diagnosed as having cirrhosis after the discovery of ascites. CC-related ascite patients, without symptoms indicative of SBP, were significantly more often diagnosed fortuitously than controls (Table 3). Conversely, most patients with SBP in the case group were equally symptomatic, as were most control patients with infectious ascites (Table 3).

In our study, the features suggestive of metabolic syndrome (17), including obesity, insulin resistance, type II diabetes, dyslipidemia and hypertension, were more frequently observed in patients with ascites superimposed on cirrhosis of unknown etiology, than in carefully matched control patients. These data are consistent with the presence of a metabolic disorder leading first, to a fatty liver and then to ascites via NASH, fibrosis and cirrhosis. Previous obesity was retrospectively evaluated by interviewing the patients; this may represent a bias, but body weight at the time of diagnosis of ascites would have been far more biased by the presence of advanced liver failure. In Italy, $20 \%$ to $50 \%$ of cirrhotic patients are malnourished to such an extent that the disease increases with higher ChildPugh cirrhosis scores (31). Type II diabetes is a common finding in cirrhosis as a consequence of liver failure, virtually irrespective of its etiology. However, the greater prevalence of type II diabetes, as well as the higher glucose and insulin levels, and insulin resistance found in the CC group are in accordance with a metabolic origin of liver disease. This hypothesis is also supported by a longer duration of diabetes in CC; the same applies to dyslipidemia (Table 1). The role of triglycerides as a hallmark of NASH has been repeatedly reported $(13,18)$ Triglycerides are one of the most important features of the so-called metabolic syndrome (17). We found systemic hypertension to be a significant independent predictor of ascites superimposed on CC. Angiotensin II levels may contribute to the hepatic fibrosis seen in NAFLD patients with hypertension (32). A possible mechanism is the enhanced profibrogenic cytokine transforming growth factor $\beta_{1}$ production via angiotensin II, which contributes to hepatic stellate cell activation (33-35).

Results from clinical trials indicate, ascitic fluid cultures are positive in $80 \%$ of patients with $\operatorname{SBP}(36,37)$, although in clinical practice, ascite culture is negative in more than $60 \%$ of SBP cases (38); thus, the diagnosis must be based on PMN leukocyte cell count. In agreement with these findings, our results show a significant divergence in the diagnosis of SBP between the PMN leukocyte cell count and ascitic culture, which was often negative. When we consider the control group, the incidence of ascitic infection observed in a hospital setting in this study was $23 \%$, which is in the range previously reported (10\% to $30 \%)$ (39). However, in the group of patients with CC-related ascites, the percentage was significantly higher than in the viral control group ( $58 \%$ versus $23 \%, \mathrm{P}<0.01$ ). The number of patients in the CC related ascite group having a total protein content less than $10 \mathrm{~g} / \mathrm{L}$ was also significantly higher than that of the control group (53\% versus $23 \%$, respectively, $\mathrm{P}<0.01$ ) (Table 1). The opsonic activity of ascitic fluid is proportional to the protein concentration, and SBP is more likely to occur if ascitic fluid protein is less than $10 \mathrm{~g} / \mathrm{L}$ (40).

It is not easy to explain the more frequent infection of ascitic fluid in patients with CC-related ascites. Physicians may not be inclined to give hospital care to all patients on the first episode of ascites, especially when of known etiology. Therefore, patients with a clear etiology of cirrhotic ascites are often managed as out-patients, sometimes without undergoing diagnostic paracentesis, using oral antibiotic and diuretic empirical therapies; in this way, we miss the opportunity to make many reliable diagnoses of SBP. Conversely, physicians are very prone to perform paracentesis when the pathogenesis 
TABLE 3

Presenting signs or symptoms leading to hospitalization for discovery of ascites

\begin{tabular}{|c|c|c|c|c|c|}
\hline & $\begin{array}{l}\text { yptogenic cirrhosis - } \\
\text { Group A - } \\
\text { Patients with } \\
\text { neutrocytic ascites: } \\
21 \text { of } 36\end{array}$ & $\begin{array}{c}\text { Cryptogenic cirrhosis - } \\
\text { Group B - } \\
\text { Patients without } \\
\text { neutrocytic ascites: } \\
15 \text { of } 36\end{array}$ & $\begin{array}{c}\text { Viral cirrhosis - } \\
\text { Group C - } \\
\text { Patients with } \\
\text { neutrocytic ascites: } \\
25 \text { of } 108\end{array}$ & $\begin{array}{c}\text { Viral cirrhosis - } \\
\text { Group D - } \\
\text { Patients without } \\
\text { neutrocytic ascites: } \\
83 \text { of } 108\end{array}$ & $\begin{array}{l}\text { McNemar } \\
\text { test to compare } \\
\text { proportions }\end{array}$ \\
\hline \multicolumn{6}{|l|}{ Symptoms related to } \\
\hline $\begin{array}{l}\text { spontaneous } \\
\text { bacterial peritonitis* }\end{array}$ & 15 (71\%) & $0 \%$ & $18(72 \%)$ & $0 \%$ & $\begin{array}{l}\text { NS: group A vs group C; } \\
\text { NS: group B vs group D }\end{array}$ \\
\hline $\begin{array}{l}\text { Symptoms related to } \\
\text { space-occupying ascites }^{\dagger}\end{array}$ & $4(19 \%)$ & $3(20 \%)$ & $4(16 \%)$ & $47(56.5 \%)$ & $\begin{array}{l}\text { NS: group A vs group C; } \\
\text { S: group B vs group D }\end{array}$ \\
\hline Incidental discovery $\ddagger$ & $2(10 \%)$ & $12(80 \%)$ & $0 \%$ & $6(7.5 \%)$ & $\begin{array}{l}\text { NS: group A vs group C; } \\
\text { S: group B vs group D }\end{array}$ \\
\hline $\begin{array}{l}\text { Incidental discovery during } \\
\text { scanning for HCC screening }\end{array}$ & $\operatorname{gg}$ & $0 \%$ & $3(12 \%)$ & $30(36 \%)$ & $\begin{array}{l}\text { S: group A vs group C; } \\
\text { S: group B vs group D }\end{array}$ \\
\hline $\begin{array}{l}\text { Diagnosis of cirrhosis } \\
\text { at hospitalization }\end{array}$ & $15(71 \%)$ & $11(73 \%)$ & $3(12 \%)$ & $15(18 \%)$ & $\begin{array}{l}\text { S: groups }(A+B) \\
\text { vs groups }(C+D)\end{array}$ \\
\hline
\end{tabular}

${ }^{*}$ Pyrexia, local abdominal pain/tenderness, systemic leukocytosis, rapid onset of renal failure, encephalopathy; ${ }^{\dagger}$ Distended abdomen/scrotal edema/umbilical eversion or herniation; ¥Evaluation for recent fatigue or purely incidental. HCC Hepatocellular carcinoma; HOMA-R Homeostasis model assessment parameters of insulin resistance; NS Not significant; S Significant at $P<0.05$

of ascites is to be clarified. For this reason, we selected from the hospital records only patients hospitalized for a first ascitic episode, to obtain a population in which diagnostic paracentesis had been performed for ascites. On the other hand, we cannot exclude other selection biases; patients with liver disease of viral origin, independent of the first ascitic episode, underwent more frequent medical examinations and therapeutic procedures, including oral or parenteral antibiotic therapy, for many causes, including nonhepatic ones, and it has been proven that bacterial translocation and the frequency of SBP in cirrhosis is reduced by intestinal decontamination with antibiotics (41). However, we cannot exclude that patients with CC-related ascites are prone to SBP: malnutrition-related bacterial translocation and SBP (42), and poorly controlled diabetes and obesity, as was the case in our patients with CC-related ascites, are well-known causes of malnutrition. Moreover, in obese diabetic patients, alterations in gut motility (above all, related to visceral autonomic neuropathy) (43) have been described, which could favour bacterial overgrowth (44). If bacterial overgrowth is the cause of extrabowel clinical manifestations, such as arthritis and dermatosis (treated by oral antibiotics [45] or bowel segmental surgical resection [46]), then we cannot exclude some relationship between possible bacterial overgrowth in obese diabetic patients and more frequent SBP.

\section{REFERENCES}

1. Falck-Ytter Y, Younossi ZM, Marchesini G, McCullough AJ. Clinical features and natural history of nonalcoholic steatosis syndromes. Semin Liver Dis 2001;21:17-26.

2. Clark JM, Brancati FL, Diehl AM. Nonalcoholic fatty liver disease. Gastroenterology 2002;122:1649-57.

3. Nomura H, Kashiwagi S, Hayashi J, Kajiyama W, Tani S, Goto M. Prevalence of fatty liver in a general population of Okinawa, Japan. Jpn J Med 1988;27:142-9.

4. Bellentani S, Tiribelli C, Saccoccio G, et al. Prevalence of chronic liver disease in the general population of northern Italy: The Dionysos Study. Hepatology 1994;20:1442-9.

5. Bellentani S, Saccoccio G, Masutti F, et al. Prevalence of and risk factors for hepatic steatosis in Northern Italy. Ann Intern Med 2000;132:112-7.
Indeed, bacterial overgrowth in humans is the basis of direct ethanol production (and presumably metabolism) that may alter intestinal permeability (47), which is already impaired in cirrhotic patients (48), thus promoting the bacterial translocation demonstrated in mice (49). Furthermore, we hypothesize that in CC patients, compared with controls, there may be a stronger immunodepression attributable to poorly controlled diabetes.

\section{CONCLUSIONS}

Features of multimetabolic syndrome are a common finding in patients with $\mathrm{CC}$ ascites, compared with results from patients with ascites complicating cirrhosis of well-defined viral etiology. Normal transaminase levels are a frequent feature in patients with CC-related ascites, with or without SBP. Ascites, with or without SBP, are often the first clinical complication leading to the diagnosis of post-NASH CC. Noninfectious ascites were discovered incidentally more often in the CC group than in the viral control group. SBP was equally symptomatic in a large percentage of cases and controls. Of note, the frequency of infected ascitic fluid was more than twofold greater in hospitalized patients with CC-related ascites compared with patients with ascites related to postviral cirrhosis.

6. Wanless IR, Lentz JS. Fatty liver hepatitis (steatohepatitis) and obesity: An autopsy study with analysis of risk factors. Hepatology 1990;12:1106-10.

7. Ratziu V, Giral P, Charlotte F, et al. Liver fibrosis in overweight patients. Gastroenterology 2000;118:1117-23.

8. Bacon BR, Farahvash MJ, Janney CG, Neuschwander-Tetri BA. Nonalcoholic steatohepatitis: An expanded clinical entity. Gastroenterology 1994;107:1103-9.

9. Powell EE, Cooksley WG, Hanson R, Searle J, Halliday JW, Powell LW. The natural history of nonalcoholic steatohepatitis: A follow-up study of forty-two patients for up to 21 years. Hepatology 1990;11:74-80.

10. Lee RG. Nonalcoholic steatohepatitis: A study of 49 patients. Hum Pathol 1989;20:594-8. 
11. Diehl AM, Goodman Z, Ishak KG. Alcohollike liver disease in nonalcoholics. A clinical and histologic comparison with alcoholinduced liver injury. Gastroenterology 1988;95:1056-62.

12. Itoh S, Yougel T, Kawagoe K. Comparison between nonalcoholic steatohepatitis and alcoholic hepatitis. Am J Gastroenterol 1987;82:650-4.

13. Marchesini G, Brizi M, Morselli-Labate AM, et al. Association of nonalcoholic fatty liver disease with insulin resistance. Am J Med 1999;107:450-5.

14. Cortez-Pinto H, Camilo ME, Baptista A, De Oliveira AG, De Moura MC. Non-alcoholic fatty liver: Another feature of the metabolic syndrome? Clin Nutr 1999;18:353-8.

15. Marchesini G, Brizi M, Bianchi G, et al. Nonalcoholic fatty liver disease: A feature of the metabolic syndrome. Diabetes 2001;50:1844-50.

16. Sanyal AJ, Campbell-Sargent C, Mirshahi F, et al. Nonalcoholic steatohepatitis: Association of insulin resistance and mitochondrial abnormalities. Gastroenterology 2001;120:1183-92.

17. Alberti KG, Zimmet PZ. Definition, diagnosis and classification of diabetes mellitus and its complications. Part 1: Diagnosis and classification of diabetes mellitus provisional report of a WHO consultation. Diabet Med 1998;15:539-53.

18. Matteoni CA, Younossi ZM, Gramlich T, Boparai N, Liu YC, McCullough AJ. Nonalcoholic fatty liver disease: A spectrum of clinical and pathological severity. Gastroenterology 1999;116:1413-9.

19. Poonawala A, Nair SP, Thuluvath PJ. Prevalence of obesity and diabetes in patients with cryptogenic cirrhosis: A case control study. Hepatology 2000;32:689-92.

20. Bugianesi E, Leone N, Vanni E, et al. Expanding the natural history of nonalcoholic steatohepatitis: From cryptogenic cirrhosis to hepatocellular carcinoma. Gastroenterology 2002;123:134-40.

21. Silvain C, Besson I, Ingrand P, Mannant PR, Fort E, Beauchant M. Prognosis and long-term recurrence of spontaneous bacterial peritonitis in cirrhosis. J Hepatol 1993;19:188-9.

22. Tito L, Rimola A, Gines P, Llach J, Arroyo V, Rodes J. Recurrence of spontaneous bacterial peritonitis in cirrhosis: Frequency and predictive factors. Hepatology 1988;8:27-31.

23. Follo A, Llovet JM, Navasa M, et al. Renal impairment after spontaneous bacterial peritonitis in cirrhosis: Incidence, clinical course, predictive factors and prognosis. Hepatology 1994;20:1495-501.

24. Runyon BA. Low-protein-concentration ascitic fluid is predisposed to spontaneous bacterial peritonitis. Gastroenterology 1986;91:1343-6.

25. Almdal TP, Skinhoj P. Spontaneous bacterial peritonitis in cirrhosis. Incidence, diagnosis, and prognosis. Scand J Gastroenterol 1987;22:295-300.

26. Caldwell SH, Oelsner DH, Iezzoni JC, Hespenheide EE, Battle EH, Driscoll CJ. Cryptogenic cirrhosis: Clinical characterization and risk factors for underlying disease. Hepatology 1999;29:664-9.

27. Matthews DR, Hosker JP, Rudenski AS, Naylor BA, Treacher DF Turner RC. Homeostasis model assessment: Insulin resistance and beta-cell function from fasting plasma glucose and insulin concentrations in man. Diabetologia 1985;28:412-9.

28. Katz A, Nambi SS, Mather K, et al. Quantitative insulin sensitivity check index: A simple, accurate method for assessing insulin sensitivity in humans. J Clin Endocrinol Metab 2000;85:2402-10.

29. Bonora E, Targher G, Alberiche M, et al. Homeostasis model assessment closely mirrors the glucose clamp technique in the assessment of insulin sensitivity: Studies in subjects with various degrees of glucose tolerance and insulin sensitivity. Diabetes Care 2000;23:57-63.
30. Becker U, Deis A, Sorensen TI, et al. Prediction of risk of liver disease by alcohol intake, sex, and age: A prospective population study. Hepatology 1996;23:1025-9.

31. Nutritional status in cirrhosis. Italian Multicentre Cooperative Project on Nutrition in Liver Cirrhosis. J Hepatol 1994;21:317-25.

32. Angulo P, Keach JC, Batts KP, Lindor KD. Independent predictors of liver fibrosis in patients with nonalcoholic steatohepatitis. Hepatology 1999;30:1356-62.

33. Powell EE, Edwards-Smith CJ, Hay JL, et al. Host genetic factors influence disease progression in chronic hepatitis C. Hepatology 2000;31:828-33.

34. Kim S, Ohta K, Hamaguchi A, et al. Angiotensin II type I receptor antagonist inhibits the gene expression of transforming growth factor-beta 1 and extracellular matrix in cardiac and vascular tissues of hypertensive rats. J Pharmacol Exp Ther 1995;273:509-15.

35. Friedman SL. Cytokines and fibrogenesis. Semin Liver Dis 1999;19:129-40.

36. Runyon BA, Canawati HN, Akriviadis EA. Optimization of ascitic fluid culture technique. Gastroenterology 1988;95:1351-5.

37. Castellote J, Xiol X, Verdaguer R, et al. Comparison of two ascitic fluid culture methods in cirrhotic patients with spontaneous bacterial peritonitis. Am J Gastroenterol 1990;85:1605-8.

38. Fernandez J, Navasa M, Gomez J, et al. Bacterial infections in cirrhosis: Epidemiological changes with invasive procedures and norfloxacin prophylaxis. Hepatology 2002;35:140-8.

39. Rimola A, Garcia-Tsao G, Navasa M, et al. Diagnosis, treatment and prophylaxis of spontaneous bacterial peritonitis: A consensus document. International Ascites Club. J Hepatol 2000;32:142-53.

40. Runyon BA. Patients with deficient ascitic fluid opsonic activity are predisposed to spontaneous bacterial peritonitis. Hepatology 1988;8:632-5.

41. Soriano G, Guarner C, Teixido M, et al. Selective intestinal decontamination prevents spontaneous bacterial peritonitis. Gastroenterology 1991;100:477-81.

42. Casafont F, Sanchez E, Martin L, Aguero J, Romero FP. Influence of malnutrition on the prevalence of bacterial translocation and spontaneous bacterial peritonitis in experimental cirrhosis in rats. Hepatology 1997;25:1334-7.

43. Crowell MD, Cheskin LJ, Musial F. Prevalence of gastrointestinal symptoms in obese and normal weight binge eaters. Am J Gastroenterol 1994;89:387-91.

44. Husebye E. Gastrointestinal motility disorders and bacterial overgrowth. J Intern Med 1995;237:419-27.

45. Jorizzo JL, Apisarnthanarax P, Subrt P, et al. Bowel-bypass syndrome without bowel-bypass. Bowel associated dermatosis-arthritis syndrome. Arch Intern Med 1983;143:457-61.

46. Drenick EJ, Roslyn JJ. Cure of arthritis-dermatitis syndrome due to intestinal bypass by resection of nonfunction segment of bind loop. Dig Dis Sci 1990;35:656-60.

47. Mezey E, Imbembo AL, Potter JJ, Rent KC, Lombardo R, Holt PR. Endogenous ethanol production and hepatic disease following jejunoileal bypass for morbid obesity. Am J Clin Nutr $1975 ; 28: 1277-83$.

48. Chang CS, Chen GH, Lien HC, Yeh HZ. Small intestine dysmotility and bacterial overgrowth in cirrhotic patients with spontaneous bacterial peritonitis. Hepatology 1998;28:1187-90.

49. Bjarnason I, Peters TJ, Wise RJ. The leaky gut of alcholism: Possible route of entry for toxic compounds. Lancet 1984;1:179-82. 


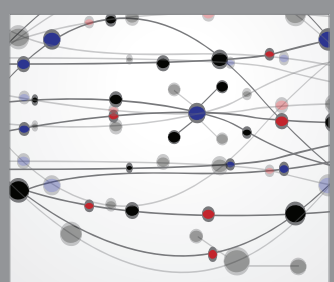

The Scientific World Journal
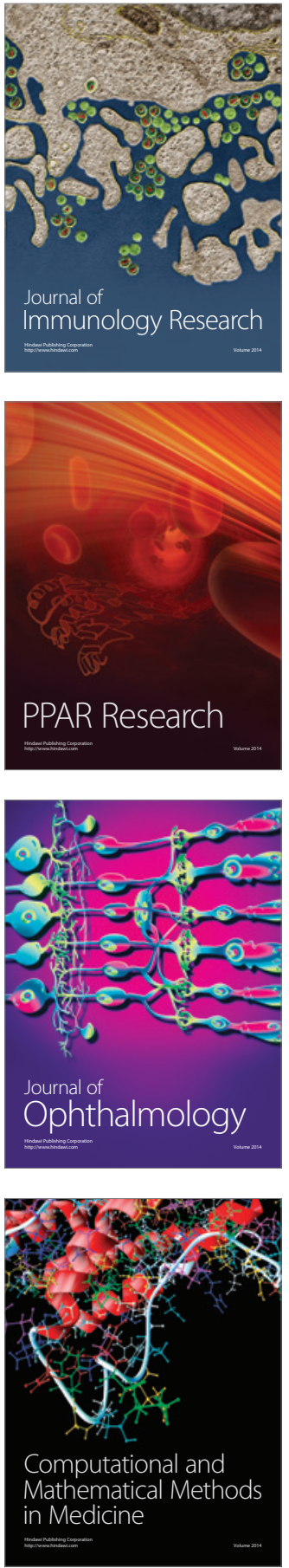

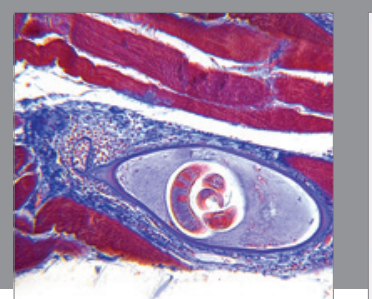

Gastroenterology Research and Practice

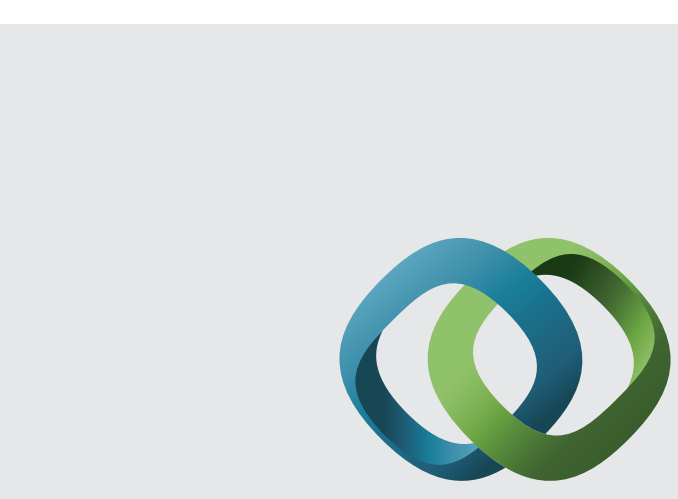

\section{Hindawi}

Submit your manuscripts at

http://www.hindawi.com
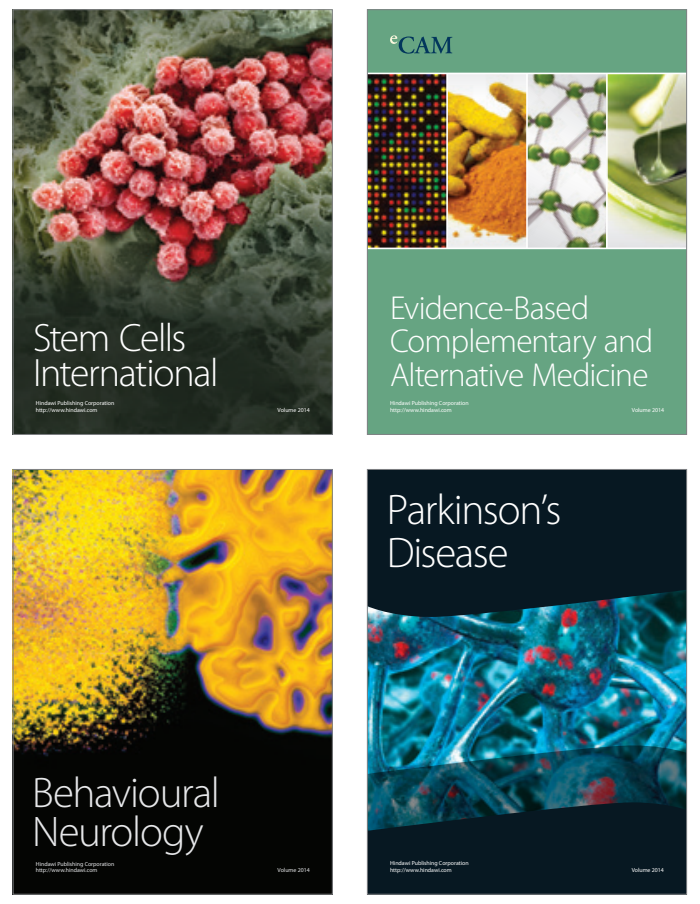
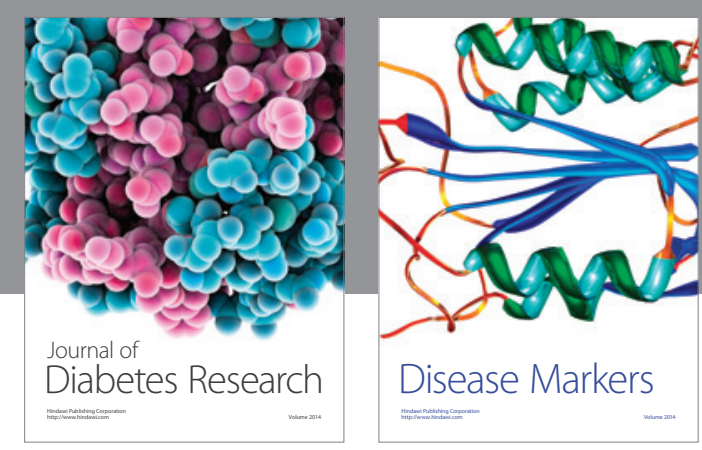

Disease Markers
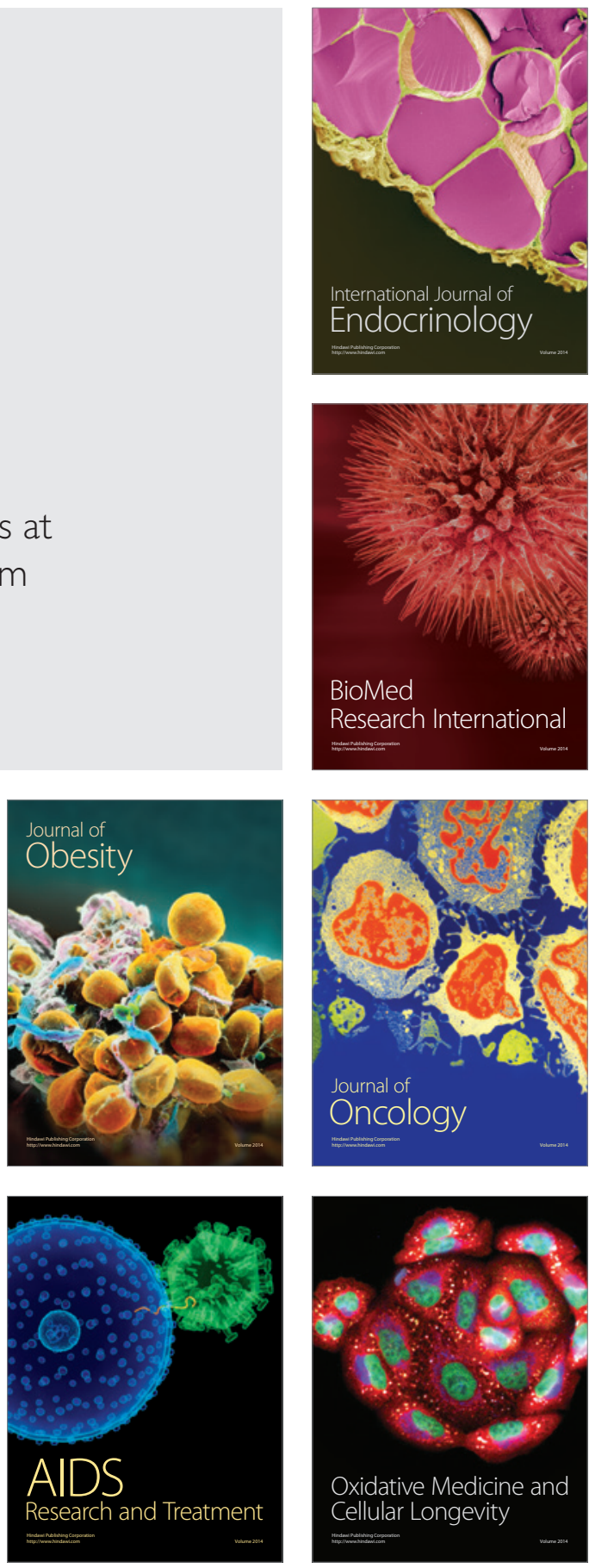